\title{
JOB SATISFACTION AND INTENT TO LEAVE AMONG GRADUATE TEACHERS IN GOVERNMENT SCHOOLS IN SRI LANKA: SPECIAL REFERENCE TO JAFFNA DISTRICT
}

\section{Kanojan.K*, Sivalogathasan. $V^{* *}$}

*Regional Manager, Ceylon Fisheries Corporation, Jaffna,kanojan1212@gmail.com

** Senior Lecturer, Department of Management Studies,

Open University of Sri Lanka, vslthasan@yahoo.com

\begin{abstract}
Job satisfaction is essential to employees to perform their duties effectively. Teachers 'job satisfaction and their intention to leave is not only important to teachers themselves but also it is very much essential to educational institutions and students as well. The purpose of this study was to find out the level of job satisfaction and intent to leave among Graduate Teachers in Government Schools in Jaffna District along with personal characteristics and job characteristics factors. This study was a quantitative approach and used the questionnaire for data collection. 200 graduate teachers participated. The findings indicated that the level of satisfaction of income, working condition and intrinsic reward was low, moderate, and moderate respectively. Also, these three independent variables influence teachers' intention to leave. Further, this study found that personal characteristics such as; age, gender, marital status, and qualification and job characteristics such as teaching experience, present position, school level, subjects teaching and preferred subjects have no significant relationship with intention to leave. The results of this study support to achieve the organizational effectiveness by studying the impact of job satisfaction and intent to leave among graduate teachers in government schools, and suggest policies or practices that can be used to enhance the employee job satisfaction and organizational performance.
\end{abstract}

Key Words: - Intent to leave, Job satisfaction, Work condition, Intrinsic rewards, personal characteristics, Job characteristics.

\subsection{Introduction}

Sri Lanka has a free education system until the first graduation. Education in Sri Lanka had been considered a fundamental right by the law. The responsibility for education in Sri Lanka is shared by the Government as well as the Provincial Councils. The Ministry of Education is the central government agency which is mainly responsible for the education in the country. The total adult literacy rate 
is $92 \%$; this is the highest in the South Asia and literacy rate among youth is $97-99 \%$. This research focuses on identifying the factors affecting intend to leave among graduate teachers specially teaching the in government school in Jaffna District of Sri Lanka. Graduate teachers are at satisfactory level with their job in a Sri Lanka context, while they are dissatisfied with the salary and physical facilities in the school, female teachers were highly satisfied than male teachers, and there was no significant correlation between job satisfaction level and age or experience level and type of schools Chandradasa, (2014). The purpose of this study is to examine the factors that are associated with intend to leave, using a structured questionnaire; the study investigates whether teachers' intention to leave differs significantly about job satisfaction, personal characteristics and job characteristics.

Every organization's most important resource is the human resource. The organization's productivity is basically depending on the effectiveness of the workforce. The organization can replace productive physical resources such as machines and equipment easily but it is difficult to replace skilled and qualified employees at once. So office worker's job satisfaction is very important because the employees are the decision makers, in the organization and direct the organization in to a success (Michael Armstrong, 2009). Likewise, the teachers occupy an important and unique place in school education. Their job satisfaction is an important factor for the achievement of educational aims and objectives of the school system. Attempts to improve performance in schools will never succeed if teachers' job satisfaction is ignored (Lise \& Timothy, 2004). Motivated and satisfied school teachers are most likely to affect the students' learning positively while the opposite of that may have negative impacts on students' performance (Fredy, 2009).

Jean \& Stanley (2014) defines job satisfaction as the response of the individual towards the role played at work. Even Zorlu (2009) describes that it is related with the individual need, and job satisfaction can be classified as per the needs of the individual. It is the feeling associated with the mind and environment which individual lives in. Paul \& Rebecca (2012) expresses as a positive perception of the individual with the work he does.

In order to achieve the organizational effectiveness the organization should have a well-defined Human resource policies and practices. By studying impact of job satisfaction and intent to leave among graduate teachers in government schools, can suggest policies or practices that can be used to enhance the employee job satisfaction and organizational performance. Many researchers reported that individuals who are in a high job satisfaction are also in a high life satisfaction and they are actively participate in their jobs rather than leaving from their current jobs, because the job satisfaction is greatly connected with person's life. Job satisfaction has a great effect on one's career life. If the employees are satisfied, there is no absenteeism, turnover in that particular organization, although 
research shows that satisfied employees have lower levels of absenteeism than do dissatisfied employees, satisfied employees have lower levels of turnover while dissatisfied employees have higher levels of turnover (Stephen \& Mary 2012). In this research following general categories are believed to influence employee job satisfaction: personal characteristics, job characteristics, working condition, income and intrinsic rewards organizational culture.

\subsection{Research Problems}

Teachers' commitment and effectiveness exclusively depend on job satisfaction of their jobs. Teachers' job satisfaction is not only important to teachers themselves but also it is very much essential to educational institutions and studies of students as well. Graduate teachers are at satisfactory level with their job in a Sri Lanka context. They are highly satisfied with the opportunity they got to serve the society while they are dissatisfied with the salary and physical facilities in the school Chandradasa, (2014), but graduate teacher's works absenteeism (10.7) and work leaving percentages (19.8) are seemly higher than trained teachers in the northern province. On the other hand, although several studies conducted about job satisfaction, even it was difficult to find out literature related to factors due to intend to leave of graduate teachers in Jaffna District. So this situation leads to generate the research problem "What is the actual reason to intent to leave among Graduate Teachers in Jaffna District?"The background of the research and formulated problem statements led to have the following research question. "To what extent the teachers' job satisfaction, personal characteristics and job characteristics influence their intention to leave, among Graduate teachers teaching in Government School of Jaffna District?"

\subsection{Objectives of the Study}

$>$ To identity the level of intent to leave among Graduate Teachers in Government Schools in Jaffna District of Sri Lanka.

To determine intent to leave among Graduate Teachers with regard to the Job Satisfaction, Personal characteristics and Job characteristics.

The retention of public school teachers has been an issue of continuing concern. This study provides information regarding the retention of teachers who teach emotionally view their teaching careers, as well as administrative supports. Findings have revealed critical predictors that affect teachers' decisions to either stay or leave teaching for other opportunities. In addition, findings from this study may be provided useful recommendations to policy makers that should enhance future recruitment and retention program strategies for teachers.

\subsection{Literature Review}

\subsection{Job satisfaction}

Upon reviewing various literatures, it has been found that many experts have explored into the subject of job satisfaction and have come out with various kinds' definitions of job satisfaction. Stephen \& Mary (2012) explain that Job satisfaction refers to an 
employee's general attitude toward his or her job. Although job satisfaction is an attitude rather than a behavior, it's an outcome that concerns many managers because satisfied employees are more likely to show up for work, have higher levels of performance, and stay with an organization. Job satisfaction refers to a person's general attitude toward his or her job. A person with a high level of job satisfaction has a positive attitude towards his or her job. A person who is dissatisfied has a negative attitude. When people speak of employee attitudes, they usually are referring to job satisfaction.

But Robert \& Paul (1991) explain that is an optimum positive felling derived after the completion of a task to achieving the target of the organization and in return the worker is rewarded either in cash or kind. Jean \& Stanley (2014) defines job satisfaction as the response of the individual towards the role played at work. Even Zorlu (2009) describes that it is related with the individual need, and job satisfaction can be classified as per the needs of the individual. It is the feeling associated with the mind and environment which individual lives in. Paul \& Rebecca (2012) expresses as a positive perception of the individual with the work he does.

Looking through all these various definitions and concepts provided by various experts, one can see that there is various similarities and dissimilarities but however concludes in the similar note at the end, therefore, it can be concluded that, Job satisfaction refers to a person's general attitude toward his or her job. A person with a high level of job satisfaction has a positive attitude towards his or her job. A person who is dissatisfied has a negative attitude, and it is the optimum level of positive feeling an attitude derived from the work and towards work and finally it is the feeling associated with the mind and the environment the individual lives in. At last job satisfaction refers to a person's general attitude toward his or her job. A person with a high level of job satisfaction has a positive attitude towards his or her job. A person who is dissatisfied has a negative attitude. When people speak of employee attitudes, they usually are referring to job satisfaction.

Job satisfaction is a multidimensional phenomenon and it is therefore argued that different scholars identify different job satisfaction factors. The phenomenon of job satisfaction is associated with following factors namely:

\section{Pay and Income:}

Wages and salaries are important factors for job satisfaction. Money not only helps personnel attain their basic needs but also instrumental in providing upper-level needs satisfaction. People with higher income are more satisfied with their job than the individuals with lower income. But money cannot term as the most determinant factor contributing to the job satisfaction but money make things worthwhile. Income level is associated with status, lifestyle and independence (Fredy, 2009).

The teacher's commitment can be improved and their degree of satisfaction could be improved, by identifying the impact of compensation. The compensation has optimistic relationship with the commitment and job satisfaction. 
According to the several researchers, a dynamic association exists between salary and satisfaction of job. Pay is the major forecaster of job satisfaction. It is the amount of monetary compensation that is expected by the workers in relationship with the services provided to the institution (Muhammad et.al, 2014). Research findings implied that teachers' salary is an important factor that contributes to teachers' job satisfaction and educational planners should consider the importance of increasing teachers' salaries in order to retain teachers in the teaching profession. Several studies suggested that job satisfaction is enhanced when workers perceive equitable pay compared to their input. When workers feel that they are inequitably remunerated dissatisfaction sets in and the larger the reward the more the job satisfaction of a worker (Michael, 2012).

\section{Working Conditions:}

Generally, employees are satisfied with physical surroundings which are not dangerous or uncomfortable. Providing good physical working conditions (e.g. cleanliness of the working place, lightning, adequate tools and equipment) enables employees to carry out their jobs easily, comfortably and efficiently. Working conditions such as flexible time, job sharing and shorter work weeks are quite valued by employees because they can facilitate valued off the job activities such as pursuing hobbies. Most employees also value a location close to home, new buildings, cleanliness, and adequate tools and equally as working conditions (Fredy, 2009).
The intrinsic factors such as achievement, recognition, the work itself, responsibility, advancement, and growth. There is effect of intrinsic rewards on employee satisfaction. Intrinsic rewards motivate employees and have significant importance, recognition is the most important reward for an employee; through recognition they become satisfy and stay with the organization. These rewards enhance the satisfaction of employees. The research study reveal that financial rewards are not important in all situations. The rewards other than financial may also matter for the satisfaction of the employees. The opportunities to learn skills and advancements are important for work satisfaction. There is positive relationship among autonomy, leadership behavior team working environment and job satisfaction. The recent results told that more autonomy in the work place increases the job satisfaction of the employees. Job autonomy, job performance feedback and clarity which is significantly correlated with job satisfaction (Tausif, 2012).

\section{Intrinsic Rewards:}

An intrinsic reward is an intangible award of recognition, a sense of achievement, or a conscious satisfaction. For example, it is the knowledge that you did something right, or you helped someone and made their day better. Because intrinsic rewards are intangible, they usually arise from within the person who is doing the activity or behavior. So 'intrinsic' in this case means the reward is intrinsic to the person doing the activity or behavior. Professional derives greater rewards from works, including the challenge of their work, the use of the 
skills and knowledge, the opportunity for self-development, learning, and growth (Fredy, 2009).

Working condition is defined as the perceived entirety of non-economic fundamentals that provides surroundings to an academician's job. Working environment is another characteristic that has a major control on the work satisfaction degree of the workforce. Schools can enhance this degree of individual's performance by enhancing job satisfaction with reward and working conditions. Providing excellent corporal working environment (sufficient and relevant tools and equipment for teaching, cleanliness of the working place and class room and, lightening) enables employees to perform their work without difficulty and professionally. Excellent work-conditions like clean and attractive environment facilitate workers to carry out their work easily and thus are expected to have an optimistic impact on job satisfaction (Muhammad et.al, 2014).

\subsection{Personal Characteristics}

\section{Gender:}

The research conducted among Canadian teachers revealed that job satisfaction levels differ significantly between male and female teachers. Similarly, the results of research that was conducted in the United States revealed that there were significant differences in the levels of job satisfaction between male and female teachers. They say that female teachers were more satisfied with their job than male teachers (Fredy, 2009).

\section{Age:}

The relationship between the job satisfaction and age can be explained through a U-shaped graph, it explains that the level of satisfaction is very high in the initial phase and start to decline and reaches to such a crucial level whereby it reaches a point of extinction but takes a turn and gears up towards the optimum level of satisfaction with the age. Even there are no strong literature concerning the relationship between the job satisfaction and the age. Findings of a study conducted among teachers in Finland revealed that there was a strong relationship between the teacher's age and job. They found that teachers' job satisfaction was linked to their age. Secondary schools teachers in United Kingdom did not differ significantly in their job satisfaction in relation to age. Work satisfaction among Chinese teachers increases with the increase in age. Similarly, it is argued that the higher the teacher's age, the higher the level of job satisfaction and the lower the teacher's age, the lower the job satisfaction (Fredy, 2009).

\section{Marital Status:}

Individual social needs can be satisfied through the love and compassionate feelings shared with the family members, spouse and other kith and kin. Empathetic and helpful family members can raise the level of Job satisfaction an individual. Researchers have discovered that the positive characters displayed in a work place are the ones coming from a wellgroomed family, these are the family 
who are very kind and helpful to others and such people tend to have higher level of job satisfaction compared to others. However Results of the research on job satisfaction that was conducted among primary and secondary school teachers in Greece revealed that there were no significant differences in levels of teachers' job satisfaction with regard to marital status (Fredy, 2009).

\section{Qualification:}

The fresh graduates with higher qualifications are not satisfied with the ordinary job they do. The study of job satisfaction of the private and public employee, reveal that qualification as a variable had much stronger negative job satisfaction in the private rather than in the public employees (Fredy, 2009).

\subsection{Job Characteristics}

\section{Working Experience/Length of Service:}

Working or teaching experience refers to the number of years a person has served as a teacher, the teachers with long teaching experience indicated higher levels of job satisfaction with such aspects as pay and supervision. In other words, the level of satisfaction increased with the increase in years of service in the teaching profession i.e. the level of job satisfaction and motivation among workers increases with job experience. Employees with many years of service perceived higher job satisfaction than their colleagues (Fredy, 2009).

\section{School Level/Grade:}

Various school levels differs the working environment and the work load. In a higher secondary school, teachers needs to concentrate more on the content of the subject so needs to change the pedagogy of teaching concentrating on the content. Similarly in the middle secondary school teachers need to concentrate on the student activity as well as the content of the subject. Therefore, depending on the school level, the teacher's cognitive domain and psychomotor level is challenged and if the teacher feels that the job is challenging and useful, it will lead the person to be satisfied with the work (Best \& James, 2005). However, in Sri Lanka context the national school teachers seemed to be more satisfied than provincial school teachers (Chandradasa, 2014).

\section{Promotions/Positions:}

Academicians are more motivated and dedicated to carry out a job and also more satisfied if promotion opportunities are available to them. If the schools enhanced their pay structure and provide promotion opportunities for their teachers then the teacher will show more contentment towards their job. The promotion involves the accessibility of progressive opportunities, if individual assume that they will not have much promotion possibilities then there will be negative impact as a whole. Reasonable probability of promotion according to the employee's skill and ability to make employee more faithful to their work become a foundation of pertinent workability for the employee (Muhammad et.al, 2014). Employees occupying managerial or leadership positions in the organization indicate higher levels of job satisfaction than 
others. This implies that teachers who occupied senior positions like being Deputy Principal, Senior Academic master/mistress, and Head of Department among others in their respective schools were more satisfied with their job than their colleagues without such promotional positions. Similarly, teachers who had earned promotions in their schools were more satisfied with their job than others (Fredy, 2009).

\section{Subject Combination:}

A conducted survey of secondary teachers' attitudes towards teaching subject combination and their job satisfaction which reviewed that there is a strong relationship between attitude towards teaching subject combination and job satisfaction. Positive attitude towards teaching indicated a high job satisfaction while negative attitude towards teaching conversely indicated low job satisfaction (Michael, 2012).

\subsection{Intention to Leave}

Intention to leave can be defined as contemplating quitting his or her current job. Intention to leave' was the next logical step after experienced workplace dissatisfaction. Intention to leave is influenced by a substantial number of identified factors, such as co-workers' job embedding and job search behaviors, three key factors; met expectations, job values and job attitudes that were related to intention to leave the organization, Other factors were work and family tensions and workplace bullying. Job dissatisfaction, availability of employment alternatives, low organizational and professional commitment, stress and lack of social support are the strongest predictors of turnover or intention to leave. Further heavy workloads, lack of professional commitment, low job satisfaction and career-based issues of training and development. Personal issues included burnout, and work and family conflict. Further industrial issues included dissatisfaction with the professions' salary levels, shift work or working hours and uncertain work status. Prior research has shown that job satisfaction is strongly and inversely associated with employee's intention to leave an organization. Job satisfaction significantly mediated the relationship between work stress and turnover intention; thus, higher job satisfaction decreased work stress and turnover intention. In other words, more satisfied employees are less likely to seek a new job, with a new employer (Salman, 2014). For the past few decades, employee retention has been of interest to researchers and employers in various fields. To remain competitive in the rapidly expanding global economy and to keep pace with technological advances requires a workforce with robust institutional knowledge; therefore, employee retention is of great importance to businesses or any type of organization.

Traditionally, studies have shown that employees tend to leave their jobs because of unfavorable work experience, above all job dissatisfaction. Working conditions, such as interpersonal treatment, peer relations, leadership style and support, school climate, problems with student behavior and the handling of student discipline, parental support, 
and promotion in school, are directly associated with teachers' job satisfaction and intention to leave (Orly Shapira, 2009).

Scholars speculate that employee turnover can be predicted using comprehensive measures of job satisfaction; otherwise stated, high job satisfaction is associated with low employee turnover. Moreover, research shows that the relationship between job satisfaction and actual employee turnover is moderated by intentions. Also it is noted that positive and statistically significant relationships have been reported in dozens of studies exploring leaving intentions and actual leaving behavior. In other words, intention to leave a job is an immediate precursor to actually leaving. For this reason turnover intention has been incorporated into most employee turnover. Turnover intention is defined as an employee's intent to find a new job with another employer within the next year. Generally, it is accepted that job satisfaction and employee turnover intention are inversely related. The established, inverse relationship between job satisfaction and employee turnover intention is very important to research in organizational behavior. One of the main goals of turnover research is to measure actual employee turnover; however, employee turnover data is often inaccessible to researchers. Frequently, this data is unavailable because it is not accurately or consistently collected. Thus, researchers must rely employee turnover intention as a proxy for actual employee turnover (Elizabeth, 2012).

\subsection{Conceptual Framework and Hypothesis}

Following variables were identified; intent to leave as dependent variable, job satisfaction as independent variable (income, working condition and intrinsic rewards) and personal characteristics (age, gender, marital status, and qualification) and job characteristics (teaching experience, position, school level, teaching and preferred subjects) are classified as moderate variables.

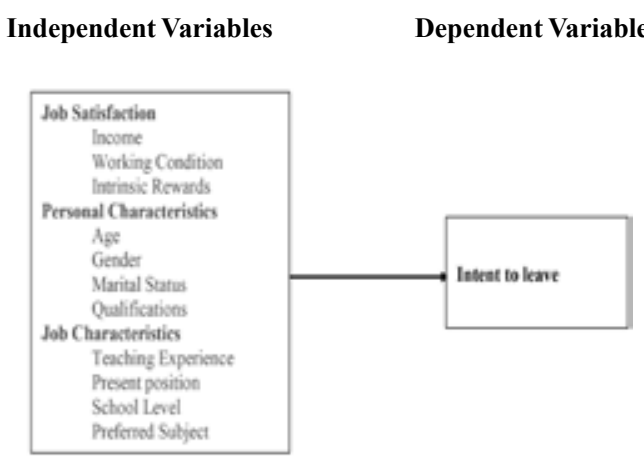

Figure 1 - Diagrammatic Representation of Conceptual Frame Work

The study research hypothesis were developed to determine the significance of the Independent Variables and their relationship between the Dependent Variable. The hypothesis of this study stated as follows;

$H_{1}$ - There is a significant relationship between Graduate Teachers'Income and Intent to leave

$\mathrm{H}_{2}$ - There is a significant relationship between Graduate Teachers' Working Condition and Intent to leave

$H_{3}$ - There is a significant relationship between Intrinsic Rewards of Graduate Teachers' and Intent to leave 
$\mathrm{H}_{4}$ - There is a significant relationship between Graduate Teachers' Personal Characteristics and Intent to leave

$H_{4 a-}$ There is a significant relationship between Age and Intent to leave

$H_{4 b-}$ There is a significant relationship between Gender and Intent to leave

$H_{4 c}$. There is a significant relationship between Marital Status and Intent to leave

$H_{4 d}$-There is a significant relationship between Qualifications and Intent to leave

$\mathrm{H}_{5}$ - There is a significant relationship between Graduate Teachers' Job Characteristics and Intent to leave $H_{5 a-}$ There is a significant relationship between Teaching Experience and Intent to leave

$H_{5 b}$. There is a significant relationship between Present Position and Intent to leave

$H_{5 c-}$ There is a significant relationship between School level and Intent to leave

$H_{5 d-}$ There is a significant relationship between Teaching Subject and Intent to leave

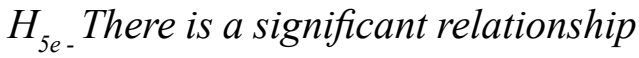
between Preferred Subject and Intent to leave

\section{Research Methodology}

This research mainly uses quantitative design, for which data were collected through simple pre-tested structured questionnaires. Multi Stage Random Sampling is performed by the method of simple random sampling. The Jaffna district has 449 schools, out of those; 06 national schools, 40 Type $1 \mathrm{AB}$ schools, 51 Type $1 \mathrm{C}$ schools, 152 Type 2 schools and 200 Type 3 schools. A grand total of 7546 teachers are enrolled in the various schools in the district out of which 3377 as graduate teachers, by considering type of schools, 200 graduate teachers were randomly selected out of 3377 graduate teachers.

Multi Stage Random Sampling is performed with the selection of school samples according to the level of school classified into national schools, Grade 1 AB Schools, Grade 1C Schools, Grade 2 Schools and Grade 3 Schools by the method of simple random sampling Table 3.1 .

Table 3.1 - Sampling Method

\begin{tabular}{|l|c|c|c|}
\hline \multicolumn{1}{|c|}{ Type of School } & $\begin{array}{c}\text { Number of } \\
\text { Schools }\end{array}$ & $\begin{array}{c}\text { Number of graduate } \\
\text { teachers }\end{array}$ & $\begin{array}{c}\text { Number of } \\
\text { sample teachers }\end{array}$ \\
\hline National Schools & 06 & 365 & 18 \\
\hline Grade 1 AB Schools & 40 & 1024 & 70 \\
\hline Grade 1C Schools & 51 & 973 & 56 \\
\hline Grade 2 Schools & 152 & 780 & 41 \\
\hline Grade 3 Schools & 200 & 235 & 15 \\
\hline Total & 449 & 3377 & 200 \\
\hline
\end{tabular}


The research instrument selected for this research was the structured pre tested questionnaire. To collect the data the researcher personally visited the selected schools and met with the Principals and explain the purpose of the visit and handed over the questionnaires to the Principals. The researcher request the Principals to distribute to the teachers and collected after two weeks. The questionnaires were distributed to 200 graduate teachers teaching in government school of Jaffna District, which is the total sample strength the response was very positive $100 \%$ respondent. After the collection of the data, the data was analyzed by using SPSS.

\subsection{Findings and Discussions}

\subsection{Sample Descriptions}

Out of 200 graduate teachers, half of the i.e. $55.5 \%$ which constitute 111 graduate teachers fallen under the age group of 30 39 years. Majority of the respondents were (67\%) females constitute of 134 numbers. Seventy seven percent of the population were belongs married followed by single status $(20.5 \%)$. Out of the total population 158 graduate teachers were Bachelor degree holders which constitute of $79.4 \%$.

Among the 200 graduate teachers, $62 \%$ had a service period of between 5-9 years. Majority of the graduate teachers $(82 \%)$ were belongs to teacher profession as a present position in the school followed by sectional head (11\%). With regard to the school level, $35 \%$ with 70 respondents teaching in the Type $1 \mathrm{AB}$ school followed by $28 \%$ with 56 teachers teaching in the Type $1 \mathrm{C}$ school. Results indicated that the teaching and preferred subjects of the teachers' varies $25.5 \%$ which constitute of 51 graduate teachers were teaching and willing to teach in primary subjects.

\subsection{Job Satisfaction and Intent to leave}

The satisfaction levels were grouped based on the mean value of the score obtained. Those mean values are interpreted as follows; Low satisfied (1.00 - 2.33), Moderate satisfied (2.34 - 3.66) and High satisfied (3.67 -5.00).

Table 4.1 demonstrates satisfaction level on working condition is moderate with average mean value of 2.578 , satisfaction level on income is low with the mean value of 1.911 , satisfaction level on intrinsic rewards is moderate satisfaction level with the mean value of 3.374 and satisfaction level on intent to leave is satisfied for intention to leave with the mean value of 3.467 . There by the findings of overall satisfaction level were moderate with the average mean value of 2.832. So out of four independent variables working condition and income level are associated with un-satisfaction condition, intrinsic rewards were related with moderate level satisfaction and intent to leave mostly related to satisfaction condition for the intention to leave. 
Table 4.1 - Summary of Overall Job Satisfaction and Intent to Leave

\begin{tabular}{|c|c|c|l|}
\hline Statement & Mean & $\begin{array}{c}\text { Standard } \\
\text { Deviation }\end{array}$ & $\begin{array}{c}\text { Level of } \\
\text { Satisfaction }\end{array}$ \\
\hline 1. Job Satisfaction & 2.832 & .511 & Moderate \\
\hline Working Condition & 2.578 & .514 & Moderate \\
\hline Income & 1.911 & .453 & Low \\
\hline Intrinsic Rewards & 3.374 & .559 & Moderate \\
\hline 2. Intent to Leave & 3.467 & .519 & Moderate \\
\hline
\end{tabular}

The research question was to conform income $(\mathrm{r}=-0.512) \&$ intrinsic rewards that are any differences exist between $(r=-0.370)$ and regression analysis intent to leave versus independent between jobsatisfaction and intent to leave variable, so findings related to research demonstrated that according to Table 4.3, question answers were mentioned as; working condition $(p=0.000)$, income according to the correlation analysis Table $\quad(p=0.000)$ and intrinsic rewards $(p=0.000)$ 4.2 indicated that there was a negative showed a significant relationship with linear correlation between intent to leave intent to leave. Therefore hypothesis $\mathrm{H}_{1}$, versus working condition $(\mathrm{r}=-0.418), \mathrm{H}_{2}$ and $\mathrm{H}_{3}$ were accepted.

Table 4.2 - Correlation Analysis between Job Satisfaction and Intent to

I a ave

\begin{tabular}{|l|l|c|c|}
\hline \multicolumn{2}{|c|}{ Variables } & $\begin{array}{c}\text { Intent to } \\
\text { leave }\end{array}$ & Sig. \\
\hline \multirow{3}{*}{ Job Satisfaction } & Working Condition & -.418 & .000 \\
\cline { 2 - 4 } & Income & -.512 & .000 \\
\cline { 2 - 4 } & Intrinsic Rewards & -.370 & .000 \\
\hline
\end{tabular}

Table 4.3 - Regression Analysis between Job Satisfaction and Intent to Leave (Coefficients)

\begin{tabular}{|l|c|c|c|c|c|}
\hline \multirow{2}{*}{ Model } & \multicolumn{2}{|c|}{$\begin{array}{c}\text { Unstandardized } \\
\text { Coefficients }\end{array}$} & $\begin{array}{c}\text { Standardized } \\
\text { Coefficients }\end{array}$ & \multirow{2}{*}{ S } & \multirow{2}{*}{ Sig. } \\
\cline { 2 - 5 } & B & Std. Error & Beta & t & .000 \\
\hline Constant) & 5.196 & .268 & & 19.399 & .000 \\
Working Condition & -.692 & .107 & -.418 & -6.473 & .000 \\
Income & -.483 & .058 & -.512 & -8.386 & .000 \\
Intrinsic Rewards & -.533 & .095 & -.370 & -5.610 & .000 \\
\hline
\end{tabular}

a. Dependent Variable: Intent to Leave

\subsection{Personal Characteristics on Intent to Leave}

The research findings indicated answers for the third research question, do any differences exist, intent to leave with regard to personal characteristics, According to table 4.4 and 4.5 the correlation analysis between age and intent to leave illustrated a positive linear correlation $(\mathrm{r}=0.074)$. Differences of age has a relationship $(\mathrm{p}=0.375)$ with intent to leave. There was a positive linear correlation between intent to leave 
versus gender $(\mathrm{r}=0.057)$, marital status $(\mathrm{r}=0.065)$ and qualification $(\mathrm{r}=0.009)$. The gender $(\mathrm{p}=0.516)$, marital status $(\mathrm{p}=0.843)$ and qualification $(\mathrm{p}=0.802)$ showed a very week relationship with in intent to leave, but not at $5 \%$ level of significance. , Therefore hypothesis $\mathrm{H}_{4}$ were not accepted.

Table 4.4 - Correlation of Personal Characteristic and Intent to Leave

\begin{tabular}{|l|c|c|c|c|c|}
\hline \multirow{2}{*}{ Model } & \multicolumn{2}{|c|}{$\begin{array}{c}\text { Unstandardized } \\
\text { Coefficients }\end{array}$} & $\begin{array}{c}\text { Standardized } \\
\text { Coefficients }\end{array}$ & & \\
\cline { 2 - 4 } & $\mathbf{B}$ & Std. Error & Beta & t & \multirow{2}{*}{ Sig. } \\
\hline Constant) & 5.196 & .268 & & 19.399 & .000 \\
\hline Working Condition & -.692 & .107 & -.418 & -6.473 & .000 \\
Income & -.483 & .058 & -.512 & -8.386 & .000 \\
Intrinsic Rewards & -.533 & .095 & -.370 & -5.610 & .000 \\
\hline
\end{tabular}

Table 4.5 - Regression Analysis between Personal Characteristics and Intent to Leave (Coefficients)

\begin{tabular}{|c|c|c|c|c|c|}
\hline \multirow[b]{2}{*}{ Model } & \multicolumn{2}{|c|}{$\begin{array}{c}\text { Unstandardized } \\
\text { Coefficients }\end{array}$} & \multirow{2}{*}{\begin{tabular}{|c|}
$\begin{array}{c}\text { Standardized } \\
\text { Coefficients }\end{array}$ \\
Beta \\
\end{tabular}} & \multirow[b]{2}{*}{$t$} & \multirow[b]{2}{*}{ Sig. } \\
\hline & B & Std. Error & & & \\
\hline (Constant) & 3.179 & .209 & & 15.224 & .000 \\
\hline Teaching Experience & .054 & .036 & .114 & 1.523 & .129 \\
\hline Present Position & .024 & .035 & .051 & .674 & .501 \\
\hline School Level & .011 & .020 & .039 & .539 & .591 \\
\hline Teaching Subjects & .010 & .010 & .073 & 1.023 & .307 \\
\hline Preferred Subjects & .010 & .010 & .073 & 1.023 & .307 \\
\hline
\end{tabular}

Regression analysis between personal characteristics and Intent to leave demonstrated that according to Table 4.5 , age $(\mathrm{p}=0.375)$, gender $(\mathrm{p}=0.516)$, marital status $(\mathrm{p}=0.843)$, and qualification $(\mathrm{p}=0.802)$ showed no significant relationship with intent to leave. Therefore hypothesis $\mathrm{H}_{4 \mathrm{a}}, \mathrm{H}_{4 \mathrm{~b}}, \mathrm{H}_{4 \mathrm{c}}$ and $\mathrm{H}_{4 \mathrm{~d}}$ were not accepted.

\subsection{Job Characteristics on Intent to Leave}

According to research result on Table 4.6 and 4.7 ; indicated that there was a positive linear correlation between intent to leave versus job characteristics such as years of teaching experience in years $(r=0.094)$, present position in the school $(r=0.018)$, school level ( $r$ $=0.025)$ teaching subjects $(r=0.068)$ and preferred subjects $(r=0.068)$. The model analysis demonstrated that year of teaching experience in years $(p=0.129)$, Present position in the school $(\mathrm{p}=0.501)$, School level $(p=0.591)$, Present teaching subjects $(\mathrm{p}=0.307)$, and preferred subjects $(p=0.307)$ have a relationship with intent to leave but not at $5 \%$ level of significance. Job characteristics with intent to leave various school levels differs the working environment and the work load. 
Table 4.6 - Correlation of Job Characteristic and Intent to Leave

\begin{tabular}{|c|c|c|c|}
\hline \multicolumn{2}{|c|}{ Variables } & Intent to & Sig. \\
\hline Job Characteristics & $\begin{array}{l}\text { Teaching Experience } \\
\text { Present Position } \\
\text { School Level } \\
\text { Teaching Subjects } \\
\text { Preferred Subjects }\end{array}$ & $\begin{array}{l}.094 \\
.018 \\
.025 \\
.068 \\
.068\end{array}$ & $\begin{array}{l}.093 \\
.398 \\
.362 \\
.171 \\
.171\end{array}$ \\
\hline
\end{tabular}

Therefore, depending on the school level, the teacher's cognitive domain and psychomotor level is challenged and if the teacher feels that the job is challenging and useful, it will lead the person to be satisfied with the work (Fredy, 2009). Same study showed that teachers' attitudes towards teaching subject combination and their job satisfaction which reviewed that there is a strong relationship between attitude towards teaching subject combination and job satisfaction. However, this study concluded that job characteristics has a no significant relationship with intent to leave, therefore hypothesis $\mathrm{H}_{5}$ was not accepted.

\section{Table 4.7 - Regression Analysis between Job Characteristics \& Intent to Leave (Coefficients)}

\begin{tabular}{|l|c|c|c|c|c|}
\hline \multirow{2}{*}{\multicolumn{1}{c|}{ Model }} & \multicolumn{2}{|c|}{$\begin{array}{c}\text { Unstandardized } \\
\text { Coefficients }\end{array}$} & $\begin{array}{c}\text { Standardized } \\
\text { Coefficients }\end{array}$ & \multirow{2}{*}{ S } & Sig. \\
\cline { 2 - 5 } & B & Std. Error & Beta & t & .000 \\
\hline (Constant) & 3.179 & .209 & & 15.224 & .000 \\
\hline Teaching Experience & .054 & .036 & .114 & 1.523 & .129 \\
\hline Present Position & .024 & .035 & .051 & .674 & .501 \\
\hline School Level & .011 & .020 & .039 & .539 & .591 \\
\hline Teaching Subjects & .010 & .010 & .073 & 1.023 & .307 \\
\hline Preferred Subjects & .010 & .010 & .073 & 1.023 & .307 \\
\hline
\end{tabular}

Regression analysis between Job characteristics and Intent to leave demonstrated that according to Table 4.7 , teaching experience $(\mathrm{p}=0.129)$, present position $(\mathrm{p}=0.501)$, School level $(\mathrm{p}=0.591)$, Teaching subjects $(\mathrm{p}=0.307)$ and preferred subjects $(\mathrm{p}=0.307)$ showed no significant relationship with intent to leave. Therefore hypothesis $\mathrm{H}_{5 \mathrm{a}}, \mathrm{H}_{5 \mathrm{~b}}, \mathrm{H}_{5 \mathrm{c}}$. $\mathrm{H}_{5 \mathrm{~d}}$ and $\mathrm{H}_{5 \mathrm{e}}$ were not accepted.

\section{Conclusions and Recommendations 5.1 Conclusions}

On reviewing the result of the research, it was found that satisfaction level of working condition and intrinsic rewards was moderate but the satisfaction level of income is low. Also, the overall satisfaction level was moderate. There was a negative linear relationship between the said three components of job satisfaction and intention to leave.

This paper further examined that reasons behind the working condition fallen in the moderate level category due to teachers are enjoyed lack of freedom in their schools or place of work followed by colleagues value their contribution very low in the school. Muhammad et.al (2014), excellent work-conditions like clean and attractive environment facilitate workers to carry out their work easily and enables teachers to perform their work without difficulty and professionally thus are expected to have an optimistic impact on job satisfaction. 
The satisfaction level on income was low due to they felt that their income were not adequate to their educational qualification was highly unsatisfied followed by they were not happy with their present fringe benefits, their salaries were not sufficient to meet all important expenses and they were not paid with appropriate wage level for the amount of work. Research findings implied that teachers' salary is an important factor that contributes to teachers' job satisfaction. Several studies suggested that job satisfaction is enhanced when workers perceive equitable pay compared to their input. When workers feel that they are inequitably remunerated dissatisfaction sets in and the larger the reward the more the job satisfaction of a worker (Michael, 2012).

Overall satisfaction level on intrinsic rewards were moderate due to teachers felt to be selected as a school principal were very satisfied followed by most of them were looking opportunity to attend workshop or seminar. The opportunities to learn skills and advancements are important for work satisfaction. There is positive relationship among autonomy, leadership behavior team working environment and job satisfaction. The recent results told that more autonomy in the work place increases the job satisfaction of the employees. Job autonomy, job performance feedback and clarity which is significantly correlated with job satisfaction (Tausif, 2012).

Findings revealed that intent to leave factors were moderate satisfied and teachers looking for chances to another job rather than teaching were satisfied, followed by moderate satisfaction of refrain their present teaching jobs any time. Indications are that employees are more likely to stay when there is a predictable work environment. Time pressure, excessive work demand and role conflicts, are causes of job stress; job related stress causes lack of commitment in the organization; and job dissatisfaction make employees to quit(Muhammad et.al, 2014). Low salary has often been found to be a significant predictor of teachers' intent to leave (Orly Shapira, 2009). A study, revealed that intrinsic rewards strongly associated with intention to leave and intrinsic satisfaction displaying stronger influence on intention to leave (Henry, Motena \& Casius, 2013). So finally according to first research question, working condition, income, intrinsic rewards factors, personal characteristics and job characteristics were the identified as factors affecting intent to leave among graduate teachers in Jaffna District.

Further researcher defined the second objective as; to determine intent to leave among Graduate Teachers with regard to the Job Satisfaction (income, working condition and intrinsic rewards); there was a negative linear correlation between intent to leave versus working condition, income \& intrinsic rewards. However working condition, income and intrinsic rewards showed a significant relationship with intent to leave. To determine intent to leave among Graduate Teachers with regard to the Personal characteristics and Job characteristics. The Personal characteristics factors of age, gender, marital status and qualification showed that there is no significant relationship with intent to leave. Mean while Job characteristics factors of teaching experience, present position, school level, present teaching subjects and preferred subjects also showed that there is no significant relationship with intent to leave. Findings reflect that the personal characteristics and job characteristics factors have no significant relationship with the intent to leave. One possible reason for this could have been the said 
factors are indirectly influencing the independent variables of job satisfaction such as working condition, income and intrinsic rewards $\left(\mathrm{H}_{1}, \mathrm{H}_{2}\right.$ and $\left.\mathrm{H}_{3}\right)$. And also commitment for social, culture of society, context and important of job and education could influence personal characteristics and job characteristics.

According to Fredy, (2009); the satisfaction level of worker are highest for those who come from a well-groomed family and who is surrounded by love and compassion of the dear and near ones, empathetic and helpful family members can raise the level of job satisfaction of an individual and the probable reason for the single workers to have lesser job satisfaction is they are lonely and always mobile and don't have any one to share any sort of feelings. Likewise the result also indicated that the qualifications don't have any impact of level satisfaction and intent to leave. Fredy, (2009) stated that; the fresh graduates with higher qualifications are not satisfied with the ordinary job they do and the study of job satisfaction of the private and public employee, reveal that qualification as a variable had much stronger negative job satisfaction in the private rather than in the public employees.

Fredy, (2009) stated that the years of teaching experience does have an impact on level of job satisfaction and intent to leave. Teachers with teaching experience of more than 30 years had a higher satisfaction level and fewer chances for intention to leave. Present position in the school identified as a one of job characteristics factors, has no significant relationship with intent to leave, and so depending on the roles played by teacher determines the level of job satisfaction and intention to leave. School level also has no significant relationship with intent to leave various school levels differs the working environment and the work load. Therefore, depending on the school level, the teacher's cognitive domain and psychomotor level is challenged and if the teacher feels that the job is challenging and useful, it will lead the person to be satisfied with the work (Fredy, 2009). Present teaching subjects and preferred subjects have a relationship with intent to leave, a conducted survey of secondary teachers' attitudes towards teaching subject combination and their job satisfaction which reviewed that there is a strong relationship between attitude towards teaching subject combination and job satisfaction. Positive attitude towards teaching indicated a high job satisfaction and fewer possibilities for intention to leave while negative attitude towards teaching conversely indicated low job satisfaction and high chances for intention to leave (Michael, 2012).

\subsection{Recommendations}

Providing good physical working conditions enables teachers to carry out their jobs easily, comfortably, efficiently, and flexible time. So it is recommended to enhance the facilities of working environment with basis technology advances. Wages and salaries are important factors for job satisfaction. It is recommended that the pay and promotion policies and procedures to be checked to ensure that they are equitable. Performance based incentive system and pay according to qualification should be incorporate to motivate teachers. An intrinsic reward is an intangible award of recognition, a sense of achievement, or a conscious satisfaction. Professional derives greater rewards from works, including the challenge of their work, the use of the skills and knowledge, the opportunity for self-development, learning, and growth. 
To provide more opportunities for carrier advancement, as an example make available chances for local and foreign training and professional development for senior teachers and sectional head in the schools, organize various level workshop, seminar and gatherings with help of various level stakeholders such as; Ministry of Education, Northern Provincial Department of Education, Northern Zonal Education Offices and some identified Non Government Organizations to enhance teachers' skills and broaden their experiences

This study identified the level of job satisfaction and intent to leave among graduate teachers in government schools in Sri Lanka: special reference to Jaffna District. As there were no studies previously conducted in this sector in Jaffna District, neither changes nor trends could be identified. Therefore, it is recommended that this study be repeated in the future to allow for comparative analysis studies and further Jaffna District, which is a suburb area, a similar kind of research can be conducted in the rural areas and make a proportional analysis.

Further, the present study conducted only for graduate teachers in government schools in Jaffna District. This should be extended into many more categories or the occupational levels such as trained teachers, private schools and semi government school teachers in various schools in Island wide base, Zonal or Provincial Educational office staff level officers of the Education Department which will give a more realistic picture and it would prove to provide more interesting result. As this investigation was limited to the graduate teachers in government schools in Jaffna District it is suggested that this be replicated to other Provinces and Districts within Sri Lanka.

\section{References}

1. Annually Bulletin of Education and Statistics (2010) Department of Census and Statistics Sri Lanka. [Online] Available from: http://www.statistics.gov.lk/ [Accessed: on 02 ${ }^{\text {nd }}$ August 2015].

2. Best W. J and James V.K, (2005) “Research in Education". 10 $0^{\text {th }}$ Ed: New Jersey Pearson Education.

3. Census of Population and Housing (2011) District Statistical Hand Book of Jaffna, Department of Census and Statistics Sri Lanka. [Online] Available from: http://www.statistics.gov.lk/. [Accessed on 30 $0^{\text {th }}$ July 2015].

4. Chandradasa. W (2014) 'Job Satisfaction of Graduate Teachers'. Department of Educational Psychology, University of Colombo, Annual Research Symposium Proceedings.

5. Fredy Wilson Ngimbudzi (2009) 'Job satisfaction of school teachers in Tanzania'. Dissertation for the Masters' Degree Thesis in Education, M.Ed. [Online] Institute of Educational Leadership, University of Jyvaskla. Available from: http://www.netlibrary.com/reader. [Accessed on $02^{\text {nd }}$ September 2015].

6. Jean M. Phillips, Stanley M. Gully (2014) "Human resource management”: South Western Ltd, U.K.

7. Lise M. Saari and Timothy A. Judge (2004) 'Employee Attitudes and Job Satisfaction'. Journal of Human Resource Management, [Online] Vol. 43, No. 4, pp. 395-40. Available from: http://www.interscience.wiley. com. [Accessed on $22^{\text {nd }}$ September 2015].

8. Michael Armstrong (2009) 'Armstrong's Handbook of Human Resource Management' Practice, $11^{\text {th }}$ Ed: Kogan Page Limited.

9. Paul Banfield and Rebecca Kay (2012) 'Introduction to Human Resource Management', $2^{\text {nd }}$ Ed: Oxford University Press, London.

10. Stephen P.Robbins, \& Mary Coulter (2012) "Management", $11^{\text {th }}$ Ed: New Jersey Pearson Education.

11. Zorlu Senyucel (2009) 'Managing the Human Resource in the 21st Century': London Business School, London. 